\title{
From Domus to Polis: Hybrid Identities in Southey’s Letters from England (1807), and Blanco White's Letters from Spain (1822)
}

Benjamin Colbert

\begin{abstract}
Robert Southey's fictive travelogue, Letters from England, by Don Manuel Alvarez Espriella (1807), inspired several imitators, most importantly José María Blanco White's Letters from Spain (1822). These works rejuvenate a fictional device popularised by Montesquieu's Persian Letters - the "familiar stranger" - at a crucial juncture when British involvement in the affairs of Europe provoked a reassessment of pre-Revolutionary cosmopolitanism. The stranger as "home-interpreter" calls attention to an emerging emphasis in European Romantic thought on the contingency of freedom with hybrid, mobile identities, prefiguring the psychosocial-historical terrain in which Jean-François Lyotard and Dean MacCannell link modernity with travel and tourism. This essay argues that the Romantic figure of the foreign traveller expresses a condition of travel, reflecting Lyotard's critique of human contingency in his essay, “Domus and Megalopolis.” Southey's sympathetic stranger modulates a conversation with Wordsworth about the nature of modern subjectivity, historically contingent yet paradoxically liberated from historical particulars. Blanco White's Letters from Spain demonstrates how displacement, emigration, and expatriation become refigured as conditions of the modern psyche, especially visible in moments of political crisis, when the cosmopolitan polis is immobilised by the myth of the domus.
\end{abstract}

Keywords: Robert Southey, José María Blanco White, Jean-François Lyotard, cosmopolitanism, travel writing, subjectivity

"Should a person be a stranger in a country, or a native, to be able to give the best account of it?” This question confronts readers of travel writing in translation by foreigners on one’s home ground, and is fundamental to works like Robert Southey's Letters from England: by Don Manuel Alvarez Espriella (1807) and John Badcock’s Letters from London.

Observations of a Russian (1816), which use a fictional device popularised by Montesquieu's Persian Letters (1721) and Goldsmith's Citizen of the World (1762) - viz. that of the "familiar stranger" ${ }^{2}$ - to mask authority, desacralise national identity, and contest the imaginative spaces of local guides and tours. The same might be said for actual foreign 
writers on "home” British ground during the Romantic period, in works such as Christian Goede’s The Stranger in England (1807), Andreas Feldborg's A Dane’s Excursions in Britain (1808), Chateaubriand's Recollections of Italy, England, and America (1815), and Louis Simond's Journal of a Tour and Residence in Great Britain (1815). Whether factual or fictional, all introduce the figure of the foreigner as home-interpreter at a crucial juncture of national self-reflection, when British involvement in the affairs of Europe provoked a reassessment of the pre-Revolutionary cosmopolitan. The home-interpreter in these works relocates politics in domesticity and domestic manners, inflected by a tension between the nostalgic "home" of rural England and the alienated home of the metropolis, what, in an imaginative essay, Jean-François Lyotard calls “Domus and the Megalopolis.”3

The domus is the focal point of myth, narrative, and belonging, with its antithesis being the "metropolis,” that is, a state of consciousness dominated by an urban awareness of the contingency of human relations and relationships. The metropolis both preserves the myth of the domus in the mutual gestures of nostalgia and utopian dreaming, and at the same time in Lyotard's words - "gnaw[s] away at the domus and its community,” until the metropolis itself becomes the dehumanised, “mechanographically operated,” megalopolis. "Home” in the megalopolis is reduced to "residence"; in the countryside, the mythic preserve of the domus, the megalopolis "stifles and reduces res domesticae ... to tourism and vacation." ${ }^{4}$ As in his earlier Postmodern Condition, Lyotard's critique is directed at the inhuman, advanced utilitarianism of late capitalism. Yet his dystopic vision of the economic functionalism of the megalopolis is less important here than his analysis of the tension between myths of belonging, or home, and the mobile identities that he associates with metropolitan communities. Easily missed in the poetic language of Lyotard's essay is the fact that domus and polis are not opposites. For Lyotard concedes that there is a way of looking at (or perhaps we should say, reading) the domus through Freud's notions of heimlich and unheimlich so 
that the domus always contains within itself and represses that which threatens, contradicts, or nullifies it. The metropolis gives a voice to the contradictions latent within the domus, calling attention to the bucolic myth of stasis and rootedness that recurs in the name of the domus, for example, at times of nationalist struggle or conflict. The nationalist becomes, in Lyotard's terms, homo re-domesticus and “takes the visitor hostage. He persecutes anything that migrates.” ${ }^{5}$ In this sense, the visiting stranger in the works considered here, becomes a metropolitan figure at the heart of Romanticism’s longing for, in Coleridge’s words, “a place of retirement, ${ }^{\prime 6}$ but a place that does not compromise or cover over political and social commitment. "Love of nature,” to Wordsworth, must lead to "love of mankind,"7 although the path by which it does so exceeds and destabilises the myths of belonging by which it is signposted.

The metropolitan modernity that inevitably succeeds the domus, or rather, expresses its contradictions, is what might be called a "condition of travel." In this condition the domus (or the Romantic myth of retirement in Nature), is exposed as an "impossible dwelling," and is replaced by - again in Lyotard’s words - “transit, transfer, translation and difference. It is not the house passing away, like a mobile home, or the shepherd's hut, it is in passing that we dwell." ${ }^{8}$ In other words, the domus, supported and nurtured by the myths of rootedness, is transformed into a phenomenological process of being, or intransitive becoming. Identity does not express homology with a state, but with mobility itself. More influential for travel theory, Dean MacCannell also considers travel as the condition of modernity, and the tourist as "one of the best models for modern-man-in-general"; ${ }^{9}$ like an aesthetic, tourism involves the repeated and ritualised consumption of sights, preserving in this experience a desire for authenticity, although never authenticity itself. Tourism as artifice, thus, becomes the sign of modernity's (and postmodernity's) nostalgia for the domus, the integration of a reality that 
now seems at best fragmented, distant, and disparate, and which, at worst, tends towards selfdestruction and genocide.

This essay argues that the figure of the foreign traveller as home-interpreter in Romantic Period literature for the first time embodies or expresses this condition of travel both in terms of what Lyotard calls the reduction of "res domesticae ... to tourism and vacation,” as well as in the ways that the metropolis, particularly embodied in London, haunts Romantic literature as the city of “transit, transfer, translation, and difference," containing and contesting the new dynamics of British power, confidence, and international presence. ${ }^{10}$ My principal focus is on Robert Southey’s Letters from England, ostensibly “translated” from the Spanish, but presenting Southey's own reflections on national cohesiveness, temper, and character, modulated through the voice of a sympathetic stranger. Among Southey’s interlocutors is Wordsworth, their conversation being about the nature of modern subjectivity, historically contingent yet paradoxically liberated from historical particulars. I then turn to one of Southey’s other auditors, the expatriate Spanish controversialist José María Blanco White. Blanco White is best known today for his liberationist Spanishlanguage journal, El Español, directed from London to the emergent South American republics in the post-Napoleonic ferment (Simón Bolívar being among Blanco White’s devoted readers). ${ }^{11}$ However, Blanco White is also a special kind of home-interpreter, one who adopted England as his home from 1811 until his death, where he composed, among other things, his Letters from Spain (1822) under the pseudonym of Don Leucadio Doblado, or “double-white,” a pun on his own name. Purportedly written from Spain, the book is characterised by fictive underpinnings that recall Southey’s performance, and Doblado himself pays tribute to “our famous Spanish traveller, my relative, Espriella," adding, “for you know that there exists a family connection between us by my mother's side.”12 Gesturing here to an intimacy that began with a gift from Southey of Letters from England in 1811, ${ }^{13}$ 
Blanco White suggests that Letters from Spain may form a sequel to Southey's book. Yet rather than a sequel, Letters from Spain is more a mirror-image, in which displacement becomes refigured as a condition of the modern psyche when the polis is immobilised by the myth of the domus, or, in Blanco White's terms, when liberty (of ideas, conscience, and even movement) is occluded by the "Bastilles of superstition"14 erected everywhere in Spain by an intransigent Catholic Church.

Southey’s stranger, the Catholic Espriella, travels to England during the Peace of Amiens, and writes home to his "Father confessor.” Espriella is accepted into a London family and draws on information provided by his hosts and the evidence of his eyes, commenting on English manners, national character, and religion. The varieties of religious dissent - and the gullibility of the English in falling for extremes - form a particular focus, with letters ranging from Quakerism, Methodism, and Swedenborgianism, to the millenarian ranting of Joanna Southcott, ${ }^{15}$ not to mention accounts of popular manifestations of credulity in shows and quack medicines: "the wild Indian woman," "the Cordial Balm of Gilead," “magnetic girdles,” and “the learned pig.” Southey has Espriella inveigh against ill effects of "heretical" divergences from "the true religion" as the root cause of much that is wrong with English Life, yet Espriella's observations are minute, his reasoning sound, his learning trustworthy, and his censure mild. ${ }^{16}$ In Espriella, English readers are invited to see themselves, as they might judge what is foreign to them - and as they might be judged. ${ }^{17}$ And they are invited to re-imagine the familiar as foreign; to put their own "domestic" myths of national unity, common interest and feeling, to the test.

Letters also stages a subtle dialogue between Southey and Wordsworth, one that turns on the meaning of "home.” As W. J. B. Owen first demonstrated, Southey’s Letters contain numerous echoes of The Prelude, the poem that Wordsworth was writing as the two poets relocated near each other in the Lake District after $1799 .{ }^{18}$ Owen cites these parallels as 
evidence of Southey being privy to the Prelude manuscript, but the relationship between these works has more profound implications when we consider both writers' sense of "home" and “travel.” “A traveller I am,” writes Wordsworth, “and all my tale is of myself” (bk. 3, lines 196-7), two propositions that seem at odds, except insofar as travel itself becomes a condition for the modern subject. In the poem, this condition of travel is landscaped by a departure from the "home” of Wordsworth’s nativity and the return to or discovery of a "home" that integrates imaginative possession of place with the political consciousness (and consequences) of his place in society.

The "Glad Preamble" - the title used to designate the first 54 lines of The Prelude offers a paean to "home," or homesteading; Wordsworth asks, "in what vale / Shall be my harbour, underneath what grove / Shall I take up my home” (bk. 1, ll. 11-13). But this kind of homesteading relies on travel, the "enfranchisement” (bk. 1, l. 9) that is also a taking stock of one’s place in the world. "Home," for Wordsworth, is not the same as his "sweet birthplace" (bk. 1, l. 278). It instead embodies and enables “restlessness” of imagination. Chateaubriand formulates a similar problem in his Recollections (1815). "If man were not attached, by a sublime instinct to his native country," he writes, "his most natural condition in the world would be that of a traveller. A certain degree of restlessness is forever urging him beyond his own limits." ${ }^{19}$ In The Prelude, great statements of this "something ever more about to be” (bk. 6, l. 542) quality of the imagination often accompany travel vignettes - the Crossing of the Alps (bk. 6, ll. 488-573), the Cave of Yordas (bk. 8, ll. 711-741), the Climbing of Snowdon (bk. 13, 1l. 1-65) - and the metaphor of "homelessness" also comes to signify the power of imaginative dwelling in the travel analogies from MS W intended originally to gloss the Snowdon lines, and in those well-known lines themselves:

... we stood, the mist

Touching our very feet; and from the shore 
At a distance not a third part of a mile

Was a blue chasm, a fracture in the vapour,

A deep and gloomy breathing place, through which

Mounted the roar of waters, torrents, streams

Innumerable, roaring with one voice.

The universal spectacle throughout

Was shaped for admiration and delight,

Grand in itself alone, but in that breach

Through which the homeless voice of waters rose,

That dark deep thoroughfare, had Nature lodged

The soul, the imagination of the whole.

(bk. 13, ll. 53-65, my italics)

The visionary moment is a moment of stasis ("we stood”) that interrupts and terminates the ascent of Snowdon, while the spectacular nature of the tableau imposes aesthetic distance that distinguishes early-nineteenth-century travellers’ customary search for the sublime and picturesque in nature. Yet the "breach,” figured as a metropolitan “thoroughfare,” its ceaseless movement and roar being correlatives of homelessness and travel, emphasizes the contingency of dwelling, picked up in the verb “lodged.” However, in the Glad Preamble, the prospective "home" seems to resolve this tension between restlessness and attachment, and it also appears to represent a place fundamentally immune to (or immured from) the upheavals of political society. Nevertheless, astute readers such as David Simpson have shown that Wordsworth's domus is undermined by the polis; ${ }^{20}$ Wordsworthian solipsism and selfcongratulation thinly conceal anxieties over the politics of retirement that come to the fore in books detailing his residence in London. 
Southey began Letters from England in October 1803, but turned in earnest to the project a year later, just at the time that he was contemplating a removal to London. In a letter to John Rickman, there may even be a glance at The Prelude's Glad Preamble in his allusion to Milton: “[T]he World is all before me ... [and] I am almost as much unprepared for the occasion \& as little furnished as Adam himself." ${ }^{21}$ (Wordsworth had celebrated his escape from city walls, "The earth is all before me-with a heart / Joyous, nor scared at its own liberty” [I, 15-16].) Keswick remained Southey’s permanent residence; but Letters from England like The Prelude records the anxieties of homelessness and the ideals of retirement from the polis. It does this far less overtly than Wordsworth’s poem, for Espriella's letters are not ostensibly about himself. Yet we can discern the Spaniard accommodating himself to his hosts, learning from them, adopting their values, and becoming more like them. ${ }^{22}$ Mid-way through his travels, as Espriella tours his alter-ego’s own home county, the Lake District, the idea of an essentialised national "home" is at once imagined and destabilised: gazing on the Windermere landscape for the last time, Espriella experiences a change of heart: "for the first time [I] anticipated with fear the time when I should leave England.”23 By journey’s end, his “deeper joy in the hope of soon ... being welcomed in my father's house” is balanced against his departure "from a land in which I have enjoyed as much happiness as man can possibly enjoy in any other state than that of domestic tranquillity” (409). Following Wordsworth in The Prelude and anticipating the language of Chateaubriand, Espriella too finds himself implicated in the condition of travel.

In an early letter, Southey explores this tension between rootedness and restlessness through mild satire. Espriella considers the first of "two words ... on which these people pride themselves, and which they say cannot be translated[:] Home ... by which an Englishman means his house" (136). His reduction of the word to a synonym reveals how dexterity with language can mask want of sympathy, an inability to imagine beyond the reductions of 
translation. “[A]ssuredly,” he continues, “this meaning can be conveyed in any language without any possible ambiguity," and he illustrates the fallacy of "home" by asking whether some "exquisite lines of Catullus ... were improved in the English translation” (i.e., larum ad nostram rendered as “our own abode” in John Nott’s 1795 translation) (137). ${ }^{24}$ Of course, the analogy can be turned around; larum (from lar "gods of places, or presiding deities") is not only not improved but it is also imperfectly rendered by “abode,” and Espriella’s next example of an "untranslatable” word from the Spanish, solár or "the floor of a house," similarly proves that to speak and to own a language are different things: "the English have not merely no equivalent term,” writes Espriella, "but no feeling correspondent to it. That reverence for the seat of our ancestors, which with us is almost a religion, is wholly unknown here” (137). Edmund Burke, for one, would have disagreed with the second half of this proposition, deploying as he does in any number of places a determined feeling for ancestors, anticipating even Espriella's diction in such works as the much reprinted Speech on Conciliation with America: "I set out ... with a profound reverence for the wisdom of our ancestors, who have left us the inheritance of so happy a constitution ....”25 In this manner, through Espriella, who reveals his own national pride parsing solár, Southey invites his readers to examine theirs in terms of the hallowed notion of "home," with Espriella effectively bringing terms together that Southey, following Burke, would suggest should inform British self-examination: “home,” “reverence,” and “religion.”

Yet to "home,” “reverence,” and "religion,” Southey adds the notion of "travel” in his assessment of British national character. This comes indirectly through Espriella's second example of a so-called untranslatable word, "comfort": "it means all the enjoyments and privileges of home, or which, when abroad, make us feel no want of home” (137). This proposition leads Espriella into a wry commentary on artificial conveniences - the "Patent Compound Concave Corkscrew" and "Pocket-toasting-forks" - produced by a fashion for 
novelty, with an implicit glance back at a previous letter in which he praises a "kitchen-range ... constructed upon the philosophical principles of Count Rumsford." "I could not but admire," he continues there, "the comfort and cleanliness of every thing about the kitchen" (130; 130-31). Behind both letters is a review published in the Anti-Jacobin Review of MarcAugust Pictet's Voyage de trois mois, en Angleterre, en Ecosse, et en Irlande (1802). Pictet writes of Count Rumford's house, "I cannot even picture to my fancy a life more pleasant, more comfortable (why may we not receive a word which our language wants?) than that which is passed here," to which the reviewer replies, "because comfortable is not a term that is not wanted in the language of Frenchmen, since it is a feeling of which Frenchman have never had any idea, and which they seem very far from being in the way to acquire.”26 Southey's intervention counters the jingoism of the Anti-Jacobin reviewer, for Espriella reveals that even comfort can be taken to extremes not befitting its possessors. Southey also shifts the focus from anti-Jacobin mudslinging to the domus and its discontents, where the German Rumford stove grafted onto the English hearth reveals how “domestic habits” can be modified by a trans-European circulation of ideas and commodities. In addition, the translations of "home” and “comfort” create an unresolved tension - despite the satiric overtones - between “domestic habits” (96) and mobility. Southey’s point is that home in translation seems to be about transit. But as Neil Leach reminds us in his own excellent reading of Lyotard, “the 'wanderer' is the element that cannot be controlled, cannot be domesticated, cannot be contained within the logic of the domus."27

In an echo from The Prelude that Owen does not remark, Wordsworth offers another context for Espriella’s difficulty with "house” and "home.” Recalling his residence in London, Wordsworth describes the feeling of being both in transit and in transition: "To have a house, / It was enough—what matter for a home?_ / That owned me, living chearfully abroad" (VII, 76-7). The "logic of the domus" here is that we may own a house, but a home 
owns us, - where possession consists, as Shelley writes in a Wordsworthian moment, of “our Poets \& our Philosophers our mountains \& our lakes, the rural lanes \& fields ... \& the affections of the mind ... inseparably united” with the phrase, "my country.”28 For Espriella and the young itinerant Wordsworth of book 7, London is the city of houses, surfaces, shows, glitz, and rapid mobility; indeed, most of the allusions that Owen catalogues concern Southey’s and Wordsworth’s descriptions of such: the “endless labyrinth of streets” (106); “dead wall[s] ... covered with printed bills” (108); beggars with their coloured chalks (109), “the gaming-houses in St. James’s street” (111) and the like. Both writers associate the experience of London with foreign travel. While Espriella first tours the metropolis "with an English gentleman, well acquainted with the manners and customs of foreign countries” (119), Wordsworth describes London’s “broad highway appearance, as it strikes / On strangers of all ages” (VII, 155-6). Both are overwhelmed by the foreignness of the familiar, and yet both are drawn to the polis as the embodiment of political consciousness, the essentials of national character, the true test of the individual's love for and connection to his or her own kind.

Inevitably the crisis of national identity occurs on the road. Having previously debunked "home” - or so he thinks - Espriella turns in letter 30 to "home-sickness” “a disease which has no existence in a certain state of civilisation or of luxury, and instead of it these islanders are subject to periodical fits of what I shall beg leave to call oikophobia" (188). Thus begins a satire on what John Scott would later call the Englishman's “travelling propensity,” which, according to Scott, appears to the French also as “a species of derangement.” ${ }^{29}$ Espriella remarks on the seasonable flight from comfort and home to the sea coasts and hot-wells, or:

to the mountains of Wales, to the lakes ..., or to Scotland; some to mineralogize, some to botanize, some to take views of the country,- -all to study the picturesque, a new 
science for which a new language has been formed, and for which the English have discovered a new sense in themselves, which assuredly was not possessed by their fathers. (189)

Though Espriella’s tongue is firmly in cheek, he nevertheless adopts the persona of pedestrian traveller and embarks on his own picturesque tour to the Lakes, finding along the way a new sense of - if not in - himself. Reviewing Letters for the Edinburgh Review, Francis Jeffrey remarked, "we bestow on this part of the book our unqualified praise": "During the whole of this excursion, we lose sight almost entirely of the character of the foreigner which the writer has undertaken to support.”30 To be sure, Southey’s Commonplace Book suggests that Southey draws on "the journals of my own tours," some probably in the company of Coleridge. ${ }^{31}$ But the section also finds Espriella identifying more closely with the English, becoming like a resident exile, one who fears return to his native land but cannot find a “dwelling place” abroad.

The key passage - quoted in full by Jeffrey - is Espriella’s vision of Derwentwater, a dream-like idealisation of the domus, in which the English res domesticus seems for a moment to be within even the stranger's grasp. The tableau begins with a "dwelling-house . . . which promised all the conveniences and elegancies of life ... in a little island the whole of which is one garden” (238). Notwithstanding the satire of the earlier letter on luxury and conveniences, Espriella imagines “home” as a place of self-sufficiency, self-enclosure, and completion. The contrast between "dwelling-place" and mountains that gives him "the same sort of pleasure that a tale of enchantment excites” is really no contrast at all. The entire world reflected in "the great mirror" of the lake is reduced to the stasis between dream and reality, a Wordsworthian border situation but for the absence of motion, mobility, and transition. There are "motionless" clouds; “not a breath of air [is] stirring”; the lake mirrors the landscape, effacing difference: "the single houses standing far up in the vale, the smoke 
from their chimneys - every thing the same, the shadow and the substance joining at their bases, so that it was impossible to distinguish where the reality ended and the image began" (238). But nothing happens. There is no Romantic epiphany to complicate and complete this vision of “home”; and Espriella’s repeated references to enchantment, romance, and dream indicate its impossibility. Despite the promised harmony between domus and Nature, the climbing of Skiddaw the next day proves as anti-climactic as can be. It is a rain-soaked affair in which nothing is seen distinctly (instead, the travellers are told what they would have seen by their guide). Upon achieving the summit, Espriella and his companion carve their names in a rural seat already covered with such marks (239); the next day they plan further excursions by viewing an "exhibition of paintings of the Lakes, a few doors distant” (239). The res domesticus of the domus has been surely reduced, in Lyotard's words again, "to tourism and vacation.” Espriella returns to London and critique, closer to understanding the meaning of "home" but as alienated as the English from it.

Letters from England is not a bildungsroman. (Like Montesquieu's, Southey’s book is more satire and social critique; as Southey himself puts it in a memorandum, it is "a far better mode of exposing folly than novels.”32) Nor is Letters as consciously structured as The Prelude. Southey appears to have considered the journey structure generically, noting to Rickman, for example, his intention to supply stock observations on gentlemen's houses initially omitted from the description of Espriella's approach to London. ${ }^{33}$ But Southey is also interested in the "freedom” of a form in which, as he later wrote to John Murray, “it would rest with the Reader to distinguish where I was writing in a fictitious character and where thro one.”34 In the passage I have just been explicating, we learn much about the Letters when we attend to Southey's voice, and to demonstrate this, I want to turn to one more allusion to The Prelude that directs our attention from domus to polis, from Espriella's Lake District ideal to London, which is (or will become) the world of all of us. 
Behind Southey's description of Derwentwater are lines that Wordsworth wrote with the intention of explaining the disappointment felt at crossing the Alps (book 6), but later placed in book 8 to explain his first entry into London:

As when a traveller hath from open day

With torches passed into some vault of earth,

The grotto of Antiparos, or the den

Of Yordas among Craven’s mountain tracts,

He looks and sees the cavern spread and grow,

Widening itself on all sides, sees, or thinks

He sees, erelong, the roof above his head,

Which instantly unsettles and recedes-

Substance and shadow, light and darkness, all

Commingled, making up a canopy

Of shapes, and forms, and tendencies to shape ...

Which, after a short space, works less and less

Till, every effort, every motion gone,

The scene before him lies in perfect view

Exposed, and lifeless as a written book .... (VIII, 711-727)

Both passages gloss disappointing mountain climbs, yet Southey’s “great mirror” lacks all of the dynamism of the Yordas reflection - it is as if Wordsworth has anticipated how Espriella’s "perfect view" is transformed to the "lifeless book" of stock tourist response. In the lines that follow, Wordsworth also anticipates the way that Southey/Espriella compares the tableau to a "scene of enchantment," but again for quite different reasons. While Southey collapses the dividing line between image and reality, questioning the authenticity of the domus, Wordsworth's traveller finds vital images equal to “some type / Or picture of the 
world” (VIII, 736-7), effectively showing how the "lifeless book" can be transformed again through translation, transition, and travel. Wordsworth's lines also link the entry into London with the powers of imagination exercised in travel, leading us back to the polis as another kind of "home” that is never outside of history. "That vast metropolis," he writes, is "the fountain of my country’s destiny / ... / Th[e] great emporium, chronicle at once / And burialplace of passions, and their home / Imperial” (VIII, 46-51). It is the "home imperial,” Southey suggests, too, where we find the stranger most at home. Espriella’s "great mirror" reflects the London he has left, and the London to which he returns.

Blanco White’s Letters from Spain begins where Southey’s narrator ends. The fiction that Letters from Spain upholds is that the narrator, long resident in England, has returned to his native land (what Espriella calls “the land of my father”). The letters back to his adopted home, England, written in English, show that "home" can never be the same to the returning migrant; or, rather, that the sublime instinct of attachment to the native place (as Chateaubriand describes it) is forever displaced by the freedom that travel confers. Chiming with Chateaubriand, Southey, and Wordsworth, Doblado puts this feeling thus: "I have [...] brought home some of your English restlessness” (141). But Letters from Spain contains on the whole very little travel and the restlessness that Doblado feels is internalised, expressed as critique towards a society in thrall to a religion that imposes restraints or constraints on the people and is characterised by spaces of enclosure: the church, the monastic cell, the nunnery. Alluding to Espriella's charge that the English malady consists of oikophobia, fear of home, Doblado notes that his English interlocutor will "laugh" at his own monachophobia, or fear of enclosed religious spaces (8). The two phobias amount to virtually the same thing: the desire to travel. Whereas the English disease defines English character (for better or for worse), Doblado’s makes of himself, in his words, “a self-banished Spaniard” (vii). 
This is epitomised in Doblado’s first landfall, Cadiz, where transit, travel, and difference abruptly come to an end. Inauspiciously, we learn that the "attractive beauty” of Cadiz, when viewed from the sea, "rivets the eye of the navigator," a foreshadowing of the chains that bind the errant. As Doblado puts it, in what could almost be a gloomy parody of Chateaubriand's contrast between travel and attachment to home, "I had enjoyed the blessings of liberty for several years; and now, alas! I perceived that I had been irresistibly drawn back by the holiest ties of affection, to stretch out my hands to the manacles” (8). His first footsteps in Cadiz are increasingly furtive, duplicitous, and circumscribed by local custom. Hardly off ship he sees the convent of San Juan de Dios and he hears a hand-bell signifying the approach of a priest carrying the consecrated wafer to the dying, before which passers-by are obliged to kneel. In a bid for freedom, Doblado alters course and calls his guide. What happens next is this:

No sooner had I called him back, as if I had suddenly changed my mind as to the direction in which we were to go, than with a most determined tone he said, "DiosSu Magestad.” Pretending not to hear, I turned sharply round, and was now making my retreat—but it would not do. Fired with holy zeal, he raised his harsh voice, and in barbarous accent of his province, repeated three or four times, "Dios-Su Magestad;” adding, with an oath, “This man is a heretic!” There was no resisting that dreadful word: it pinned me to the ground. I took out my pocket-handkerchief, and laying it on the least dirty part of the pavement, knelt upon it—not indeed to pray; but ... to curse the hour when I had submitted thus to degrade myself, and tremble at the mere suspicion of a being little removed from the four-footed animals, whom it was his occupation to relieve of their burdens. (11)

Letters from Spain becomes a book about the dystopia of the domus, what Doblado describes as the infiltration of "religion, or, if you please, superstition" into "the whole system of public 
and domestic life” (7). The result is a static society, compartmentalised in regional identities, with few amenities for travellers let alone tourists. Hence, Doblado concentrates his narrative on the religious complexion of society rather than his own movements through it; he alludes repeatedly to a British travel book, Joseph Townsend's A Journey through Spain in the Years 1786 and 1787 (1791), for all that need be said upon this score.

In this state, as in the above passage, the traveller is by definition a heretic, an outlaw, his guide homo re-domesticus, the one who "takes the visitor hostage" and "persecutes anything that migrates," a division that comes home to Doblado at the end of his book when he gives us an account of one of the few journeys in it, his flight from Madrid to Seville on the 15th of June 1808, to join the insurrection of Andalusia soon after the French invasion of the capital. Doblado portrays a revolutionary moment in which nothing changes. As on arrival in Cadiz, when mobility could be halted with a single word, the journey to Seville is checked by mobs "who would make us pay dear for any flaw they might discover in our narratives” (380-81); ““We wish, Sir, to kill somebody,’ said the spokesman of the insurgents [in one town] ... [']we will not be behind our neighbours. Sir, we will kill a traitor’” (382). Most damning to Doblado is "the religious character which the revolution has assumed ... like a dense mist concealing or disfiguring every object which otherwise would gratify the mind” (391). Narrating his own rationale for emigration, Blanco White looks to Britain alone for the secular metropolitanism that can transform the malignant growth of the Spanish domus and effect a true Revolution, and so the book ends with a plan to help a dissenting Priest, Doblado’s alter-ego, escape to England. From there, Blanco White’s autobiographical Life (1845) continues the story with a reflection on travel itself as liberation: "I was under the British flag in the open sea, as the sun rose above the horizon. The beautiful town of Cadiz was sinking gradually behind the waters. A shade of melancholy passed over my mind, when 
I thought I should never see those buildings again; and then I gave myself up to the sublime enjoyment of the solitary expanse before me.”35

Although Blanco White along with his friends Wordsworth, Coleridge, and Southey have all been regarded as political travellers towards a reactionary conservativism, their respective notions of the domus should not be mistaken for a proto-fascist celebration of the “homeland” - indeed, White’s Letters from Spain, much appreciated by the Lake poets, warns specifically against this. All of them grow to distrust the mystique of the folk; Southey and Wordsworth in particular are too conscious that mass culture forever compromises the idyllic retreat of the countryside, except insofar as the domus can be seen as an imaginative space "divided from the world / As if it were a cave” ("Home at Grasmere”), or as a space of travel and transition (“Cave of Yordas"). Despite their impulses to retirement, what we see emerging in such works as The Prelude, Letters from England, and Letters from Spain is the post-Napoleonic reinvention of the city as the space of national re-creation, with London emerging as a special case in "home writing” both foreign and domestic, testing the grounds of national character where the stranger within us is paradoxically least and most at home.

\section{Note on Contributor}

Benjamin Colbert is Reader in English Literature at the University of Wolverhampton, and Co-Editor of European Romantic Review. He is the author of Shelley's Eye: Travel Writing and Aesthetic Vision (Ashgate 2005), and has edited a number of essay collections and scholarly editions, including Travel Writing and Tourism in Britain and Ireland (Palgrave, 2012), Women's Travel Writing in Post-Napoleonic France, vols. 5-8 (Pickering \& Chatto, 2012), and Foreign Correspondence (Cambridge Scholars Press, 2014; with Jan Borm). He founded and maintains the online open-access database, Women's Travel Writing, 1780-1840. 


\section{Notes}

${ }^{1}$ Meister, Letters Written during a Residence in England, 130. Although Meister's book belongs in the genre discussed below, I do not treat it here. See instead my account of it in "Britain through Foreign Eyes.”

${ }^{2}$ See Dalnekoff, "Familiar Stranger”; also, Ghose, "Fictive Stranger.”

${ }^{3}$ Lyotard, "Domus and the Megalopolis,” 191-204.

${ }^{4}$ Ibid., 192.

${ }^{5}$ Ibid., 197.

${ }^{6}$ See Coleridge’s “Reflections on Having Left a Place of Retirement,” Poetical Works, 106.

${ }^{7}$ Wordsworth, The Prelude [1805], bk. 8. Further citations to this edition appear in the text.

${ }^{8}$ Lyotard, "Domus and the Megalopolis," 198.

${ }^{9}$ MacCannell, The Tourist, 1.

${ }^{10}$ Lyotard, “Domus and the Megalopolis,” 193; 198.

${ }^{11}$ See Sánchez, “Romanticism and the Transatlantic Imagination.”

${ }^{12}$ Blanco White, Letters from Spain, 3-4.

${ }^{13}$ See letter 1978, “Robert Southey to Joseph Blanco White, 4 November 1811,” in Collected Letters, Part Four.

${ }^{14}$ Blanco White, Letters from Spain, 211.

${ }^{15}$ See letter 1412, “Robert Southey to James Grahame, 4 January 1808,” in Collected Letters of Robert Southey, Part Three: "Nothing renders England more remarkable to a Spaniard than the variety of religious sects which it contains: \& few subjects appeal to me more worthy of attention than the aberrations of human intellect upon the most momentous object which can ever employ it.”

${ }^{16}$ In his posthumously published Journals of a Residence in Portugal 1800-1801 (1960), Southey commences a rapprochement with the Catholic point of view that is wholly absent 
from his earlier Letters Written during a Short Residence in Spain and Portugal (1797). Of a Corpus Christi procession, Southey exclaimed, "I never saw aught finer than this, nor, indeed, to be compared with it. It ought to be seen with Catholic eyes, not with the eye of a philosopher," and later, "Religion is kept alive by images ... this puppet-show popery - is better than that execrable diabolism of Calvin. Here is something to feed the feelings, to satisfy and kindle the Imagination” (quoted in Parker, "Southey’s Politics and Travel,” 342). This willingness to see as others see, which is also the basis of Letters from England, runs counter to Indira Ghose’s argument that Southey’s “well-documented” “abhorrence for all things Catholic” (56) underpins his attempt to speak for the Spanish other in an Orientalist gesture. Rather, my argument is that Southey recognises "home” as a contingent base, a mobile identity, which must come to embody "foreign" critique if it is to meet the challenges of an internationalised cosmopolitan present.

${ }^{17}$ See Christopher Lake Moody’s unsigned review of Letters from England, 380: “[Letters from England] are not meant to flatter but to instruct; and, by removing the medium of national vanity and partiality, to enable us to see ourselves in a different glass from that which Englishmen professedly writing to Englishmen would venture to hold up. Naturally disposed to consider our country as the best of all possible countries, we do not sufficiently criticize our characteristic traits and numerous defects; and while our own travellers amuse us with the absurdities of foreign nations, we are not aware that we ourselves, on many accounts, are open to satirical animadversion.”

${ }^{18}$ Owen, “Southey’s England and The Prelude," 10-17.

${ }^{19}$ Chateaubriand, Recollections, 1:83.

${ }^{20}$ See Simpson, Wordsworth’s Historical Imagination, 108-139 passim.

${ }^{21}$ Letter 983, “Robert Southey to John Rickman, 15 October 1804,” Collected Letters, Part Three. 
${ }^{22}$ This too is the movement in Blanco White’s “Cartas de Inglaterra” (Letters from England) [1822-25] section of Variedades, a Spanish-language quarterly published in London by Ackermann and distributed in Spanish America, which follows Blanco White's progress from traveller to émigré, or, as Jocelyn Almeida puts it, “from marginalised observer of British society to critical insider.” See Almeida, “Blanco White,” 447.

${ }^{23}$ Southey, Letters from England, 246. Further citations to this edition appear in the text. "My father's house” is a phrase Wordsworth uses to describe his return to Grasmere during the Cambridge Long Vacation (bk. 5, 1. 501); for both Wordsworth and Espriella the phrase indicates a transformation of their notions of "home."

${ }^{24}$ I follow Jack Simmons in identifying “the English translation” with Nott’s, published by Joseph Johnson, though Southey’s phrasing may indicate English translations in general (see Simmons, ed., Letters from England, 94n1). Nott's translation, however, had drawn the ire of the Critical Review ("the beauty is lost in translation" [66]) and is a likely candidate for Southey's satire here.

${ }^{25}$ Burke, “Speech on Conciliation with America,” 81.

${ }^{26}$ Anti-Jacobin Review, 471. See also Southey’s poem, “Hymn to the Penates” (1797):

"home. / There is a magic in that little word: / It is a mystic circle that surrounds / Comforts and virtues never known beyond / The hallowed limit.”

${ }^{27}$ Leach, “The Dark Side of the Domus,” 153.

${ }^{28}$ Shelley, Letter 348, “To Thomas Love Peacock [15 May 1816],” in Letters, 475. In this passage, written during his 1816 Continental excursions, Shelley paraphrases and thinks through the implications of Wordsworth's Intimations Ode in terms of his own feelings towards “home.” See also Colbert, Shelley’s Eye, 92-4.

${ }^{29}$ Scott, Visit to Paris, 4-6.

${ }^{30}$ [Jeffrey], review of Letters from England, 382; 383. 
${ }^{31}$ Southey, Southey’s Common-Place Book, 353

${ }^{32}$ Ibid.

${ }^{33}$ Letter 1115, “Robert Southey to John Rickman, 27 October 1805,” Collected Letters, Part Three.

${ }^{34}$ Letter 2916, “Robert Southey to John Murray, 14 February 1817,” Collected Letters, Part Five. Southey’s comments here concern a projected sequel, Travels in England, advertised by Murray in 1814 but never executed.

${ }^{35}$ Blanco White, The Life, 1:164.

\section{Bibliography}

Almeida, Jocelyn. "Blanco White and the Making of Anglo-Hispanic Romanticism.” European Romantic Review 17, no. 4 (2006): 437-56.

Anti-Jacobin Review. Unsigned review of Voyage de trois mois, en Angleterre, en Ecosse, et en Irlande (1802), by Marc-August Pictet, Vol. 18 (1804): 469-71.

Blanco White, José María. Letters from Spain by Don Leucadio Doblado. 2nd ed. London: Henry Colburn, 1825.

Blanco White, José María. The Life of the Rev. Joseph Blanco White, Written by Himself. With Portions of His Correspondence. Edited by John Hamilton Thom. 3 vols. London: John Chapman, 1845.

Burke, Edmund. "Speech on Conciliation with America." The Works of the Right Honourable Edmund Burke. New ed. Vol. 3. London: Printed for F. and C. Rivington, 1801. 
Chateaubriand, François-René de. Recollections of Italy, England and America, with Essays on Various Subjects, in Morals and Literature. 2 vols. London: Henry Colburn, 1815.

Colbert, Benjamin. "Britain through Foreign Eyes: Early Nineteenth-Century Home Tourism in Translation.” In Travel Writing and Tourism in Britain and Ireland, edited by Benjamin Colbert. 68-84. London: Palgrave, 2012.

Colbert, Benjamin. Shelley’s Eye: Travel Writing and Aesthetic Vision. Aldershot: Ashgate, 2005.

Coleridge, Samuel Taylor. Coleridge: Poetical Works, edited by Ernest Hartley Coleridge. Oxford: Oxford University Press, 1980.

Critical Review. Unsigned review of The Poems of Caius Valerius Catullus, in English Verse, [translated by John Nott]. Vol. 22 (Jan. 1798): 65-67.

Dalnekoff, Donna Isaacs. “A Familiar Stranger: The Outsider of Eighteenth-Century Satire.” Neophilologus 57, no. 2 (April 1973): 121-34.

Ghose, Indira. “The Fictive Stranger: Oliver Goldsmith’s The Citizen of the World and Robert Southey’s Letters from England.” Journal for the Study of British Culture 4, no. 1-2 (1997): 47-61. 
[Jeffrey, Francis]. Review of Letters from England (1807). Edinburgh Review 11 (January 1808).

Leach, Neil. "The Dark Side of the Domus: The Redomestication of Central and Eastern Europe.” In Architecture and Revolution: Contemporary Perspectives on Central and Eastern Europe. Edited by Neil Leach, 150-62. London and New York: Routledge, 1999.

Lyotard, Jean-François. “Domus and the Megalopolis.” In The Inhuman: Reflections on Time. Translated by Geoffrey Bennington and Rachel Bowlby, 191-204. Cambridge: Polity Press, 1991.

MacCannell, Dean. The Tourist: A New Theory of the Leisure Class. With a foreword by Lucy R. Lippard. Berkeley and London: University of California Press, 1999.

Meister, Jacques-Henri. Letters Written during a Residence in England. London: Longman and Rees, 1799.

[Moody, Christopher Lake]. Review of Letters from England, by Don Manual Alvarez Espriella [i.e., Robert Southey], Monthly Review, n.s., 55 (April 1808): 380-86.

Owen, W. J. B. “Southey’s England and The Prelude.” The Wordsworth Circle 23, no. 1 (Winter 1992): 10-17.

Parker, W. M. “Southey’s Politics and Travel.” Quarterly Review 298 (July 1960): 333-45. 
Sánchez, Juan Luís. "Romanticism and the Transatlantic Imagination: Blanco White, Keats, and the Liberal Dilemma.” Cuadernos de Ilustración y Romanticismo 18 (2012): 127-44.

Scott, John. A Visit to Paris; Being a Review of the Moral, Political, Intellectual, and Social Condition of the French Capital. London, 1815.

Shelley, Percy Bysshe. The Letters of Percy Bysshe Shelley. Edited by Frederick L. Jones. Vol. 1. Oxford: Clarendon Press, 1964.

Simmons, Jack, ed. Letters from England by Robert Southey. London: Cresset Press, 1951.

Simpson, David. Wordsworth's Historical Imagination: The Poetry of Displacement. New York and London: Methuen, 1987.

Southey, Robert. The Collected Letters of Robert Southey. Part Three: 1804-1809. Edited by Carol Bolton and Tim Fulford. Romantic Circles Electronic Edition. http://www.rc.umd.edu/editions/southey_letters/Part_Three/index.html

Southey, Robert. The Collected Letters of Robert Southey. Part Four: 1810-1815. Edited by Ian Packer, and Lynda Pratt. Romantic Circles Electronic Edition. http://www.rc.umd.edu/editions/southey_letters/Part_Four/index.html Southey, Robert. The Collected Letters of Robert Southey. Part Five: 1816-1818. Edited by Tim Fulford, Ian Packer, and Lynda Pratt. Romantic Circles Electronic Edition. http://www.rc.umd.edu/editions/southey_letters/Part_Five/index.html 
Southey, Robert. Journals of a Residence in Portugal 1800-1801; and a Visit to France 1838. Edited by Adolfo Cabral. Oxford: Clarendon Press, 1960.

Southey, Robert. Letters from England, by Don Manuel Alvarez Espriella. Edited by Carol Bolton. London and New York: Routledge, 2016.

Southey, Robert. Southey’s Common-Place Book. Fourth Series. Original Memoranda, Etc. Edited by John Wood Warter. London: Longman, Brown, Green, and Longmans, 1850.

Wordsworth, William. The Prelude 1799, 1805, 1850. Edited by Jonathan Wordsworth, M. H. Abrams, and Stephen Gill. New York and London: W. W. Norton \& Company, 1979. 